\title{
Good Management
}

\section{De la Bonne Gestion}

\author{
John Hegarty ${ }^{1}$, Regis Maubrey ${ }^{2}$ \\ ${ }^{1}$ Ipag Business School, Paris, France, john.hegarty@ipag.fr \\ ${ }^{2}$ Ipag Business School, Paris, France, regis.maubrey@ipag.fr
}

\begin{abstract}
This paper defends a vision of good management that is rational, practical, and responsible. Managers are rational insofar as they link their actions to reasons, practical insofar as they situate their actions in context and consider the consequences, and responsible insofar as they are prepared to answer questions about the appropriateness of their actions. This paper presents a general empirical method for practicing management in this manner, together with a toolbox of good management concepts, contexts, and precepts. Attention is drawn to the role of modelling and using context in good management. The method is applied to a business case study.

RESUME. Cet article défend une vision de la bonne gestion comme rationnelle, pratique, et responsable. Les managers sont rationnels dans la mesure où ils lient l'action aux intentions, pratiques dans la mesure où ils placent l'action dans son contexte et considèrent ses résultats, et responsables dans la mesure où ils sont prêts à répondre aux questions sur le caractère approprié de l'action. Nous présentons ici une nouvelle méthode pour ces bonnes pratiques managériales ainsi qu'une boîte à outils de concepts, contextes, et préceptes. L'attention est attirée sur l'importance de la modélisation et de l'utilisation du contexte dans la gestion. La méthode est appliquée à une étude de cas.
\end{abstract}

KEYWORDS. General Empirical Method in Management, Reasons, Consequences, Appropriateness, Good Management Toolbox.

MOTS-CLES. Méthode Générale Empirique de Gestion, Raisons, Conséquences, Justesse, Boîte à outils de la Bonne Gestion.

\section{A Practice-based Approach to Management}

It has been claimed that bad management theories destroy good management practices with their "pretense of knowledge" and "ideology-based gloomy vision" (1). Scholars who promote a humancentered approach propose alternative views of what it is to be a manager, pointing to the importance of a logic of appropriateness and a concern for authenticity $(\underline{2}, \underline{3})$. In this short paper, we propose an approach to modelling and using context in management that is both human-centered and practice-based.

The rest of this short paper is organized as follows. In section 2, we present our theory of good management practice. In section 3, we present a case study of its application in a business judgment. Finally, in section 4 we draw conclusions and make recommendations for future research.graph is a classic paragragh.

\section{Good Management Practice}

In this section, we present a toolbox of concepts, contexts, and precepts of good management (Figure 2.1) together with a general empirical method for using them (Table 2.2).

\subsection{Concepts, Contexts, and Precepts}

Figure 2.1 below brings together concepts, contexts, and precepts in a toolbox for good management. 


\section{Concepts}

- Situations, Cases, Models

- Value, Stakeholders

- Corporations, Purposes

- Values, Principles, Policies

- Environments, Institutions

- Resources, Capabilities

- Positions, Performances
Contexts

- Macro-environments

- Micro-environments

- Organizations

- Functions

- Operations

- Activities

- Practices

Precepts

- Be Rational

- Be Practical

- Be Responsible

Figure 2.1. Good Management Toolbox

Using the Good Management Toolbox calls for a method, which is the topic of the next section.

\subsection{A General Empirical Method in Management}

Eight related cognitional and communicational activities are presented in this section as functional specialties of management. Each of these eight management activities intends a different type of management object. Each management object has a particular form which is a potential source of intelligibility for the manager. Each of the different forms the manager's objects of attention give rise to different types of management question. And all the management questions together constitute the context of management action in a given situation. This image of management as a group of cognitional and communicational activities organized by questions that orient human endeavor in pursuit of the common good illustrates our adaptation of Lonergan's general empirical method (4-6) to management and is presented in summary in Table 2.2 below.

\begin{tabular}{|l|l|l|l|l|}
\hline Step & Mgt Activities & Mgt Objects & Mgt Forms & Mgt Questions \\
\hline 1 & Inquiring & Differences & Data & Relevance \\
\hline 2 & Discovering & Relations & Patterns & Meanings \\
\hline 3 & Formulating & Hypotheses & Narratives & Possibilities \\
\hline 4 & Evaluating & Situations & Positions & Soundness \\
\hline 5 & Committing & Resources & Plans & Feasibility \\
\hline 6 & Instituting & Values & Principles & Acceptability \\
\hline 7 & Coordinating & Activities & Policies & Vulnerability \\
\hline 8 & Encouraging & Communities & Practices & Representation \\
\hline
\end{tabular}

Table 2.2. General Empirical Method in Management

The method is empirical because it is grounded in data, and general because the data includes data of consciousness as well as data of the senses. The next section shows how the method illustrated in Table 2.2, together with the Good Management Toolbox illustrated in Figure 2.1, and the contextual graph representation formalism, familiar to the context community, are used to model and use context in a real-world business situation. 


\subsection{A Practice-based Approach to Modelling and Using Context in Management}

The first challenge facing a manager is to understand the business situation and characterize it as an opportunity or threat. A business situation may be modelled as a value-creating activity using concepts familiar to management practitioners, scholars, and students; the choice of concepts will influence the quality of the model, which is why we include a concepts section in the Good Management Toolbox, illustrated in Figure 2.1. But in order to use the model of the business activity in a particular situation, a manager must also be able to model and use the context in which the activity is unfolding. In order to illustrate a practice-based approach to modelling and using context in management, we consider a situation that is new for the manager, a situation that calls for an ad hoc project. (If the situation is a recognizable case calling for a tried and tested process or procedure, we refer readers to the literature on case-based reasoning and judgment).

One difficulty, in unfamiliar situations, is that a manager must model the activity and the context at the same time; any element of concern may be placed either in the model of the activity (and used for reasoning in the situation) or in the model of the context (and used to recognize future situations of the same type, for reasoning about the situation). A second difficulty is that the relevant context evolves with the focus of attention as the activity unfolds. A third difficulty is that contexts are recursively nested in other contexts; the actual practice of any activity is affected by elements of the environment that bear on the activity but are not included in the model of the activity. All three difficulties are overcome by using the contextual graph approach; by representing the actual practice of the activity as a path in a contextual graph that links the relevant contextual elements to the actions that make up a particular practice of the activity. The key point is that the manager's model of the situation be practice-based and take account of the nested hierarchy of contexts. This latter point explains why we include a contexts section in the Good Management Toolbox illustrated in Figure 2.1.

So, by combining the contextual graph approach and the contexts section of the Good Management Toolbox, a manager can model and use context in support of good management. The first step of the method illustrtaed in Table 2.2 starts with inquiring into data, where data is now understood to include both data on the activity and data on the relevant context. While management practitioners, scholars, and students are familiar with Key Performance Indicators (measures of aspectual difference in the practices of an activity), our approach draws attention to the need to be attentive also to what we call Key Situation Indicators that keep track of the evolving context and are used to explain performance.

As an example of a business situation we present the case of a business manager faced with a merger opportunity; we are using the term business manager in the widest sense including top managers, public managers, entrepreneurs; the French term responsable captures better the notion we are getting at of the person in charge who takes on responsibility for the decision to take action (or not) in a particular situation. The next section shows how the method illustrated in Table 2.2, together with the toolbox presented in Figure 2.1, and the practice-based approach to modelling and using context in management are used to study a real-world business situation.

\section{A Case Study}

Recently, the Chief Executive Officer (CEO) of Veolia announced the merger of Veolia and Suez, two large French companies, and published a communication on the decision (7). As a case study in a business school, we asked students to use the method outlined in Table 2.2 together with the toolbox presented in Figure 2.1 to determine if the merger is a good decision, if it reflects good management. To this end they are required, on the one hand, to analyze the decision presented in the merger communication, and on the other hand to inquire into the person making the decision. 
The two aspects of the study are outlined in the following sections.

\subsection{Analyzing the Decision}

The decision and its implementing principles, policies, and practices are explained by Veolia as a response to the situation of ecological transformation. The meaning of ecological transformation for Veolia emerges from their insights into current and future relations and practices. The relations and practices are based on the data considered by Veolia to be relevant (for example the technologies of Veolia and Suez, to which the document draws attention) (7). It remains for the students to determine if Veolia followed the precepts of good management. If the data used by Veolia are relevant and sufficient to justify the decision, if the insights are sound and no oversights were made, if the formulation of the plan is well reasoned, and if the feasibility, acceptability, and vulnerability of the plan have been correctly evaluated, then the decision looks good.

However, to determine whether the decision really is good calls for an additional inquiry into the person of the decision maker. The questions this raises are addressed in the next section.

\subsection{Inquiring into the Person Making the Decision}

Is the CEO's judgment good? Managers, like all humans, are made by their decisions and actions, so the track record and reputation of the CEO are relevant. The inquirer's opinion may also be informed by journalists (and other investigators) and by the CEOs peers' opinions (other CAC 40 CEOs for example).

There is a lot of data available to come to an informed opinion but in order for the inquirer's opinion to be sound, it too must be based on attentive, intelligent, reasonable knowing, practical doing, and responsible being. To judge the goodness of judgment of another requires good judgment. The more we are rational, practical, and responsible in our inquiries and actions the more we can be sure of our judgments.

\section{Conclusions and Further Research}

This short paper proposes a triply normative vision of the manager, both as an individual person, and as a representative of a corporation. In both roles, rational knowing is grounded in practical doing, in turn grounded in responsible being. This vision is accompanied by an analytic toolbox and a general empirical method that may be useful to have about when confronted with teaching, researching, or dealing practically with business situations. The paper focuses on how practicebased modelling and using context support rational practical responsible management and is a step towards good management.

The authors are applying the method in the classroom in a business school in Paris and further research will involve adapting the method to the boardroom, and to the town hall.

\section{Bibliography}

[1] Ghoshal S. Bad management theories are destroying good management practices. Academy of Management learning \& education. 2005;4(1):75-91.

[2] March JG, Olsen JP. The logic of appropriateness. The Oxford handbook of political science2004.

[3] Taylor C. The ethics of authenticity: Harvard University Press; 1992.

[4] Lonergan B. Insight: A study of human understanding: University of Toronto Press; 1992.

[5] Lonergan B. Method in Theology: Volume 14: University of Toronto Press; 2017.

[6] Leplat J. De l'étude de cas à l'analyse de l'activité. Perspectives interdisciplinaires sur le travail et la santé. 2002(42). 
[7] Veolia. Together let's take on the challenge of ecological transformation. 2021. 